\title{
Chapter 9 \\ Co-composting: An Opportunity to Produce Compost with Designated Tailor-Made Properties
}

\author{
Laura Giagnoni, Tania Martellini, Roberto Scodellini, Alessandra Cincinelli, \\ and Giancarlo Renella
}

\begin{abstract}
Co-composting is a technique that allows the aerobic degradation of organic waste mixtures, primarily aiming at obtaining compost that can be used as fertiliser or soil amendment. As compared to the typical composting activity, the main difference is not merely the use of more than one feedstock to start and sustain the biodegradation process, but also the possibility of combining various kinds of waste to obtain 'tailored' products with designed properties, or to reclaim and valorise natural resources, such as degraded soils or polluted soils and sediments. Set up of appropriate co-composting protocols can be a way to optimise the management of waste produced by different sectors of agriculture and industry and also from human settlements. Different formulations can not only optimise the biodegradation process through the adjustment of nutrient ratios, but also lead to the formation of products with innovative properties. Moreover, co-composting can be a technique of choice for the reclamation of soils degraded by intensive agriculture or contaminated soils and sediments. In fact, an appropriate mix of organic waste and soils can restore the soil structure and induce fertility in nutrient-depleted soils, and also remediate polluted soils and sediments through degradation of organic pollutants and stabilisation of heavy metals. While the selection of different mixes of organic waste may lead to the design of composts with specific properties and the potential valorisation of selected waste materials, there are still several factors that hamper the development of co-composting platforms, mainly insufficient knowledge of
\end{abstract}

\footnotetext{
L. Giagnoni

Department of Agriculture, Food, Environment and Forestry (DAGRI), University of

Florence, Florence, Italy

e-mail: laura.giagnoni@unifi.it

T. Martellini $\cdot$ R. Scodellini $\cdot$ A. Cincinelli

Department of Chemistry, University of Florence, Sesto Fiorentino, Italy

e-mail: tania.martellini@unifi.it; roberto.scodellini@unifi.it; alessandra.cincinelli@unifi.it

G. Renella $(\bowtie)$

Department of Agronomy, Food, Natural Resources, Animals and Environment, University of

Padua, Legnaro, Italy

e-mail: giancarlo.renella@unipd.it
} 
some chemical and microbiological processes, but also some legislative aspects. This chapter illustrates the progress achieved in co-composting technology worldwide, some key legislative aspects related to the co-composting process, the main scientific and technical aspects that deserve research attention to further develop co-composting technology, and successful applications of co-composting for the reclamation of soils and sediments, allowing their use for cultivation or as growing media in plant nurseries. A specific case study of the production of fertile plantgrowing media from sediment co-composting with green waste is also illustrated.

Keywords Co-composting · Product design $\cdot$ Waste recycle $\cdot$ Co-composting process evaluation $\cdot$ Dredged sediments $\cdot$ Green waste co-composting

\section{Introduction}

Co-composting is the process of the aerobic degradation of organic compounds using more than one feedstock. The initial materials can be of industrial, agricultural or urban domestic household origin, and all materials allowed to be recycled as bioresources according to the local legislation. To date, reports have been published on the co-composting of sewage sludge, animal excreta, urban solid waste and plant residues, from various pilot experimental activities and industrial scale treatment plants. Since ever, composting of organic solid waste was directed towards the sanitation and volume reduction of municipal waste, with extensive efforts directed to mechanical innovations, the reduction of emissions and odours during the composting process, and speeding up of compost maturation through the achievement of a sustained thermophilic phase.

Currently, with rapid urbanisation occurring globally, organic waste represents the majority of the municipal waste in emerging countries. In this context, composting systems can play an important role in managing waste as well as creating employment and creating products that contribute to food security, particularly in developing countries. Organic solid waste collected from households and institutions is composted either at decentralised (community-based) or centralised composting plants. Community-based decentralised composting systems can generally process about 2-50 tonnes per day of organic waste, whereas centralised composting facilities are capable of receiving 10-200 tonnes per day. There are two fundamental types of composting techniques: open or windrow composting, a slower process conducted outdoors with simple equipment, and enclosed system composting, where composting is performed in a building, tank, box, container or vessel. Proper management of the plant and marketing of the compost are key factors to ensure the sustainability of such systems.

The above-mentioned global trends call for new sustainable and safe strategies for waste treatment, for their recycling and for the minimisation of landfill. Research in compost science and technology has mainly focused on the treatment and 


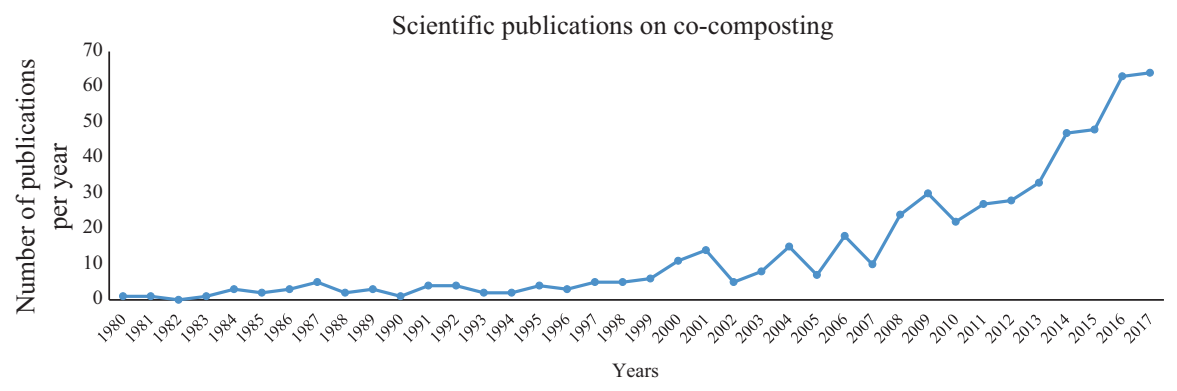

Fig. 9.1 Trend of publications using the term co-composting in the title or keywords in the period 1980-2018. (Source: Scopus, accessed on 30 December 2018)

conversion of the organic fraction of waste, mainly municipal solid waste and manure, which has represented the target fraction to be recycled because it is rich in nutrients that can be of particular benefit if they are reused as compost in agriculture as soil amendment or fertiliser (Bernstad and la Cour Jansen 2011). For example, pre-treated faecal sludge can be co-composted together with the solid waste, as faecal sludge has a high moisture and nitrogen content and biodegradable solid waste is high in organic $\mathrm{C}$ and has good bulking properties (i.e. it allows air to flow and circulate). By combining the two types of waste, the benefits of each can be used to optimise the process and the product.

Since the 1990s some new co-composting approaches have been extended to the treatment of organic waste, assisted by the use of mineral matrices, whereas cocomposting techniques aiming at the reclamation of inorganic environmental matrices such as soils and sediments are still seldom reported. A literature survey in Scopus (Elsevier) revealed that 596 articles could be retrieved using 'co-composting' as search criteria in the article title, abstract and keywords, with a marked increasing trend of scientific publications from the mid-2000s onward (Fig. 9.1). Very interestingly, while the early publications focusing on co-composting were mainly published by Western European and North American countries, the substantial growth of the literature body on the subject is mostly contributed by Asian countries, mainly China, India and Malaysia (Scopus, accessed on 30 September 2018), where this approach is significantly contributing to modernising the waste management in developing countries (Hoornweg et al. 2000).

\section{Co-composting: Organic Waste Composted with Inorganic and Biotic Additives}

The review article by Barthod et al. (2018) exhaustively illustrates how the composting of the four major categories of organic waste (food waste, green waste, municipal solid waste and sewage sludge) has been mainly conducted by mixing them with several inorganic materials and types of waste, with the aim of improving 
specific aspects of the composting process. Specific features of the composting process, such as sanitation, compost maturation and odour emission; pollutant concentrations and compost grade; nutrient content and availability; and greenhouse gas emissions have received different degrees of attention depending on the 'hot topics' under discussion by the scientific community and all stakeholders. Analysis of the literature conducted as mentioned above shows that the use of additives to the main composting waste has shifted from mainly sanitation and maturation aspects, which were important in the 1980s and the 1990s (in particular, sanitation effectiveness and compost maturation related to compost grade), towards a focus on nutrient content and availability and greenhouse gas emission, which have gained increasing attention from the 2000 s to date. These fundamental changes can be related to the improved compost science and technology, which has led to consolidated protocols of sanitation and improved sensitivity of the analytical procedures to the use of well-sorted waste, at least in the most developed countries, which prevents the presence of excessive heavy metal concentrations in the original organic materials, and to the concomitant stringent need to optimise the nutrient recycle in agriculture and minimise the greenhouse gas emissions during the composting process to protect the atmosphere. It is important to underline that the recent literature shows that although this paradigm shift was uniform across all countries, including those where waste management is not yet optimal, research on the basic processes and on the properties of the compost has not completely stopped, especially because new additives (i.e. zeolites, biochar) are being tested. However, even in the presence of major changes in scientific approaches, the use of the term co-composting was used mainly to highlight the use of additives instead of designing new processes with different waste materials.

Composting, as a process, has proven to be effective against several organic pollutants through their complete mineralisation or conversion into less toxic substances. Atagana (2004) reported that the addition of $25 \%$ of poultry manure to a contaminated soil previously mixed with $1: 1$ wood chips could reduce the polycyclic aromatic hydrocarbon (PAH) concentration more than in the soil-wood chips mixture only, to levels below $1 \mathrm{mg} / \mathrm{kg}$, mainly through the adjustment of the $\mathrm{C}: \mathrm{N}$ ratio value and temperature control, which favoured microbial proliferation. Cai et al. (2007) reported that degradation of carcinogenic PAHs in secondary dewatered sewage sludge was more rapid when mixed with rice straw, particularly when inoculated with a commercial mixed microbial/biostimulant formulation. Similar results were reported by Wan et al. (2003), who compared various mixes of pig manure, sewage sludge and soybean refuse to enhance the degradation of PAHs in a polluted soil, reaching a maximum of $90 \%$ of removal with pig manure, and for removal of total petro hydrocarbons (over 99\%) during a co-composting of a diesel oil-contaminated soil mixed with sewage sludge (Namkoong et al. 2001). Huang et al. (2016) reported that co-composting of dredged sediments with rice straw, vegetable residues and bran, and bioaugmented with Phanerochaete chrysosporium, allowed the degradation of 4-nonylphenol, a dangerous endocrine disruptor.

Aparna et al. (2008) presented a co-composting treatment for the treatment of sediments from Isnapur, Khazipally and Gandigudem lakes (India) contaminated by 
benzene, phenols, PAHs, and polychlorinated biphenyls (PCBs), mixing them with poultry manure, cow dung, urea, diammonium phosphate and sawdust in the following proportions: $70 \%$ polluted sediment $+5 \%$ poultry manure $+5-8 \%$ cow dung $+8 \%$ sawdust $+5-6 \%$ urea $+4-8 \%$ diammonium phosphate DAP, so as to adjust the initial C:N ratio value to 30 for all treatments. The results showed that all classes of organic contaminants were significantly reduced after co-composting and all maturity indices were met after a total time of 23 weeks. Similar results were reported by Rekha et al. (2005) on contaminated sediments from lakes in Hyderabad (India) co-composted with manure and sawdust at a ratio of 2:1:2. Concerning more recalcitrant compounds, Büyüksönmez et al. (1999) reported that organo-chlorinated compounds are highly resistant to biodegradation-even more than common pesticides. However, the efficiency of the degradation of chlorophenols in composting polluted soils was reported to be higher than $80 \%$ (Bentham and McClure 2003) and 90\% (Laine and Jørgensen 1997). A complex in situ technology for co-composting metal-polluted river sediments was presented by Guangwei et al. (2009), mechanically mixed with $10 \%$ in volume of wood chips, plant stems and beer-brewing waste, and inoculated with thermophilic bacteria inside a reactor capable of maintaining high temperatures. The technology made it possible to significantly stabilise $\mathrm{Cu}, \mathrm{Zn}$ and $\mathrm{Pb}$ so as to meet the environmental quality standards for surface water in China, and to allow the reuse of the reclaimed sediments for the revegetation of the local riverbank.

The above-mentioned successful studies support co-composting as a technique capable of degrading harmful organic molecules even in contaminated mineral matrices, although not much attention has been given to the design of such cocomposting processes. In this context, a co-composting study conducted by Macía et al. (2014), who adopted a co-composting approach for producing a sedimentbased technosol, suitable for plant growth, as proven by the high germination index, can be considered as some pioneering work.

\subsection{Effects of Additives on Composting Process and Compost Quality}

The vast majority of the scientific literature focusing on co-composting reports the effects of various organic and inorganic additives on the fundamental composting processes and parameters, such as maturation, nutrient losses and heavy metal availability. For example, Lefcourt and Meisinger (2001) reported that the addition of hydrated double sulphate of $\mathrm{K}-\mathrm{Al}$ or zeolite to dairy slurry at rates ranging between $0.4 \%$ and $6.25 \%$ significantly reduced ammonia volatilisation, and Venglovsky et al. (2005) reported that the addition of zeolite to pig slurry at rates of $1 \%$ and $2 \%$ reduced the compost $\mathrm{pH}$ value and a significantly higher concentration of watersoluble ammonia during the decomposition process, as compared to non-amended compost. The speeding up of the maturation of municipal solid waste composting 
process upon inoculation with fermenting bacteria and cellulolytic fungi at high microbial density ( $1 \cdot 10^{9}$ colony-forming unit CFU/ml, $5 \mathrm{ml} \mathrm{kg}$ dry mass) was reported by Wei et al. (2007) and was ascribed to the significantly increased organic matter humification as compared to non-inoculated waste. A more effective sanitation in regard to enteric and other pathogenic bacteria was obtained by mixing composting pig manure with fly ash and lime at rates of $25 \%, 33 \%$ and $50 \%$, and $4 \%$ respectively. Nishanth and Biswas (2008) reported that the addition of $4 \%$ of rock phosphate, mica and the Aspergillus awamori, to composting rice straw increased the $\mathrm{P}$ and $\mathrm{K}$ solubility and had higher fertilisation effects on wheat in pot experiments than a conventional NPK fertiliser. In a field trial located in the Tyrol region (Austria), Kuba et al. (2008) reported that the addition of bottom ash from wood incineration to a composting mixture of biowaste at rates of $8 \%$ or $16 \%$ improved the basic process parameters and the overall product quality, as long as low metal ashes were used, and similar results were reported by Belyaeva and Haynes (2009), although in the latter study the rate of ash addition was higher $(25 \%)$. Ren et al. (2009) reported that struvite addition to composting cornstalk at rates ranging between $3.8 \%$ and $8.9 \%$ significantly reduced the total $\mathrm{N}$ losses and improved the maturation, compared to the unamended compost. Steiner et al. (2010) reported a faster decomposition and a significant reduction of ammonia volatilisation, and Bolan et al. (2012) reported that the addition of clay minerals and Fe-(hydro)-xides to poultry and cow manures at rates of $5 \%(\mathrm{w} / \mathrm{w})$ produced an increase in the stabilisation of $\mathrm{C}$ attributed to its immobilisation onto the mineral phases that prevented the microbial decomposition, without a negative impact on the quality of soil amended with such compost. Concerning the dynamics of heavy metals, which generally increase their concentration due to the mass reduction during the composting process, Chen et al. (2010) reported that the addition of bamboo-derived biochar to pig manure and sawdust at rates ranging between $3 \%$ and $9 \%(\mathrm{w} / \mathrm{w})$ resulted in a significant reduction of $\mathrm{N}$ losses and significantly lower solubility $\mathrm{Cu}$ and $\mathrm{Zn}$. $\mathrm{Lu}$ et al. (2014) reported that the addition of 5\% rock phosphate to pig manure and rice straw compost decreased the availability of $\mathrm{Cu}$ and $\mathrm{Zn}$ related to the increase of the compost $\mathrm{pH}$ value organic carbon stabilisation. Khan et al. (2014) reported that the addition of biochar addition at rates of $5 \%$ and $10 \%(\mathrm{w} / \mathrm{w})$ to composting chicken manure and pine sawdust resulted in different maturation dynamics related to the increase of microbial activity, and reduced $\mathrm{N}$ losses from the composts by ammonia volatilisation and nitrate leaching, depending on the origin of the biochar. Similar results were obtained by Zhang and Sun (2014), who reported a faster decomposition of composting green waste co-composting with spent mushroom compost in the presence of biochar added at rates of $20 \%$ or $30 \%$. Czekała et al. (2016) carried out $5-10 \%$ of biochar addition to mixed poultry manure/wheat straw compost and reported that biochar addition at $10 \%$ increased the temperature but shortened the length of the thermophilic phase, results that paralleled those shown by Waquas et al. (2018), who used biochar produced from lawn waste added to food waste compost at rates of $10 \%$ and $15 \%$ to increase the velocity of organic matter degradation and compost maturity, meeting the main international compost quality standard criteria. In a complex experiment involving the use of clay minerals and biochar 
from conifer wood as additives, used singly or in combination at rates of 25-50\% and $10 \%$, respectively, Barthod et al. (2016) reported that the addition of clay and clay/biochar mixtures to composting green waste reduced the $\mathrm{C}$ mineralisation, particularly in the combined clay/biochar treatments.

\subsection{Effects of Additives on Nutrient Concentration and Greenhouse Gas Emissions}

The increasing stringency of the atmosphere protection measures imposed on all industrial processes has led to an increase in research in compost science on potential positive impacts of various additives on the abatement of greenhouse gas emissions during the composting process. Among the earlier works on this aspect, Hao et al. (2005) reported that a treatment of livestock manure with phosphogypsum at rates of between $10 \%$ and $30 \%(\mathrm{w} / \mathrm{w})$ led to a significant reduction of methane emissions, but only at the highest rate. In a study of the effects of bulking agents on the gaseous emissions of composting kitchen waste, Yang et al. (2013) showed that different bulking agents, such as cornstalks, sawdust, and spent mushroom, reduced the emissions of $\mathrm{CH}_{4}$ and $\mathrm{N}_{2} \mathrm{O}$, particularly sawdust, although they were not effective in reducing $\mathrm{NH}_{3}$ emissions. The latter study was also interesting because it attempted to calculate the $\mathrm{C}$ and $\mathrm{N}$ mass balance of the greenhouse gas emissions. Awasthi et al. (2016) reported that combinations of Ca-saturated bentonite and biochar (B) could effectively reduce the greenhouse gas emissions and nutrient losses of dewatered sewage sludge during composting. A significant reduction of greenhouse gas $\left(\mathrm{CH}_{4}, \mathrm{~N}_{2} \mathrm{O}\right)$ emissions and of odour emissions (e.g. $\left.\mathrm{NH}_{3}, \mathrm{H}_{2} \mathrm{~S}\right)$ from composting pig manure was achieved by the addition of woody peat and Ca-superphosphate, both mixed at rates of $10 \%$, although the use of superphosphate retarded the organic matter degradation because of an increase of the electrical conductivity values during the composting process. Effective control of emissions of $\mathrm{NH}_{3}$ and $\mathrm{H}_{2} \mathrm{~S}$ causing odour and of various volatile compounds also impacting the atmosphere quality, such as volatile fatty acids and carbonylic compounds, was obtained by Shao et al. (2014) by the addition of rice straw at rates of 10\%, 20\% and $30 \%$ to composting municipal solid waste. Reduced emissions of ammonia, methane and nitrogen protoxide during the composting of duck manure was reported by Wang et al. (2014), with an additional rate of $12 \%$, and a further reduction was obtained by the addition of earthworms to the co-composting materials 45 days after the beginning of the process. Maulini-Duran et al. (2014) investigated the effects of wood chips or chopped $(0.25 \times 4-10 \mathrm{~cm})$ polyethylene tubes as bulking agents on the emissions of volatile organic compounds (VOCs) and greenhouse gases from a composting organic fraction of municipal solid waste in Zaragoza (Spain). Their results showed that polyethylene tube as bulking agent reduced $\mathrm{NH}_{3}, \mathrm{CH}_{4}$ and VOCs emissions more than the wood chips, the volatile organic compounds profile was dominated by terpenes, with limonene being the most abundant, and $\alpha$ - and $\beta$-pinene 
related to the wood chops bulking agent. An approach for controlling both greenhouse gas emission and the availability of heavy metals in co-composting of a 1:1 mixture of sewage sludge and wheat straw, based on the use of biochar, was presented by Awasthi et al. (2016). Their results showed that the addition of $12 \%$ of biochar and $1 \%$ of commercial lime reduced the emission of $\mathrm{NH}_{3}, \mathrm{CH}_{4}$ and $\mathrm{N}_{2} \mathrm{O}$, and the solubility availability of $\mathrm{Cu}, \mathrm{Ni}, \mathrm{Pb}$ and $\mathrm{Zn}$. Chowdhury et al. (2014) pointed out that an optimal reduction of emissions from biochar-amended compost can be obtained when well-controlled aeration conditions can be achieved during the composting process, but this key aspect has seldom been addressed in subsequent work based on the use of biochar for minimising greenhouse gas emissions.

\subsection{Main Mechanisms Identified in Compost Science and in Co-composting Approaches}

Information available in the vast literature in compost science, along with practical experience gained by the broad spectrum of the composting community, has made it possible to identify some of the main mechanisms controlling the process and allows some fine-tuning to optimise the final product and minimise the environmental impact caused by the composting activities. Besides the well-established effects of temperature on the compost sanitation, the addition of sorbents, either natural or manufactured (e.g. clay minerals, zeolites, Fe-Al-(hydro)-oxides), generally reduce the ammonia volatilisation and heavy metal solubility through sorption mechanisms. Such inorganic additives can also improve the end product quality by increasing the total concentrations and solubility of key nutrients, such as $\mathrm{K}$ and $\mathrm{P}$, once incorporated into soil. Similarly, the positive effects of biochar on compost maturation and greenhouse gas emissions can be attributed mainly to its porosity, which create additional biological space, and is also a function of its particle size distribution (Zhang and Sun 2014) in the composting mass. This can explain the lower $\mathrm{CH}_{4}$ emissions, whereas sorption of ammonium ions that lead to reduced ammonia loss and $\mathrm{N}_{2} \mathrm{O}$ emission. Analogously, some negative effects observed from the use of other inorganic additives, such as struvite precursors, have been related to the formation of acidic Mg-phosphate salts during the struvite crystallisation, which may acidify the composting mass, leading to lower microbial activity and reduced biodegradation, as reported by Ren et al. (2009). In all the mentioned cases, the identified mechanisms highlighted an active role of the additives in the retention of macronutrients and heavy metals with specific physico-chemical mechanisms, and not their direct role in the transformation of the organic matrix of the composting mass. To our knowledge, none of the above-mentioned studies has reported the degree of alteration of the additives at the end of the composting process regardless of the used additives, except for the dissolution of some soluble salts. In this regard, a co-composting process should make it possible to design significant physical and chemical alteration of the components in the composting mass, with their 
conversion into materials with innovative characteristics at the end of the process (Fig. 9.2).

The co-composting of mineral environmental matrices, such as soils and sediments, mixed with organic matter, has shown potential to both accelerate the degradation of organic pollutants and to create new organo-mineral materials with texture, structure and nutrient contents that are suitable for their potential use in different agricultural sectors. In a co-composting approach to waste re-use, the organic matrix - either manure (Atagana 2004; Wan et al. 2003), sewage sludge (Ling and Isa 2006; Wan et al. 2003), green compost (Antizar-Ladislao et al. 2004) or municipal green waste (Belyaeva and Haynes 2009) — acts not only as the energy source for microorganisms (Englert et al. 1993), but also alters the reactivity of the mineral solid phases, changes the chemistry of the circulating solution, and confers a structure that conditions the movement of the liquid and gaseous phases at different scales.

Obviously, for an optimal co-composting process, the key parameters that control the microbial activity, such as the $\mathrm{C} / \mathrm{N}$ ratio, the moisture content and the peak temperature and length of the thermophilic phase, must be ensured. Typical values for such parameters for an efficient composting are a $\mathrm{C} / \mathrm{N}$ ratio of $25-30$, as the initial optimum value for composting (Choi 1995), a moisture range of 50-70\% (Liang et al. 2003) and minimum temperatures of $55-60{ }^{\circ} \mathrm{C}$ (Fan and Tafuri 1994), which favour microbial metabolism and population dynamics, effective sanitation and the degradation of eventual organic pollutants (Antizar-Ladislao et al. 2004). Temperature can be a critical aspect in the co-composting of mineral matrices, such as soils and sediments, as they do not provide metabolic energy and may represent a 'thermal sink' in the process, leading to so-called 'cold composting'. Composting at a low temperature presents drawbacks in terms of the presence of pathogens and germinating seeds, which are not killed during the process, the concentration of potentially phytotoxic compounds (Bernal et al. 2009), and a prolonged and difficult to estimate composting time to reach maturity. These drawbacks need to be overcome, mainly by arranging suitable volumes to retain heat-generally larger than those recommended for ordinary composting (UNEP-CalRecovery 2005), and preparing the co-composting materials in a small particle size so as to maximise the surface contact between the organic and mineral phases, and to speed up the composting process.

From the point of view of the main mechanisms influencing the co-composting of organic waste with mineral matrices in relatively high proportions (e.g. $>30 \%$ ), sorption of $\mathrm{C}$ and control of the $\mathrm{pH}$ value are expected to play major roles. In fact, microbial transformation of the organic matter mainly occurs at the liquid-solid phase interface (Bernal et al. 1998), and especially at the early stages of decomposition, sorption of low molecular weight organic matter may reduce the velocity of decomposition, leading to a cold composting process with the related outcomes listed above. Moreover, the evolution of the $\mathrm{pH}$ value of the co-composting mass may deviate from the typical trends due to the buffering capacity of the mineral phases, through the production of protons and other acidic chemical species, such as $\mathrm{NH}_{4}{ }^{+} \mathrm{HS}^{-}, \mathrm{H}_{2} \mathrm{PO}_{4}^{-}$and low molecular weight organic acids. However, the 


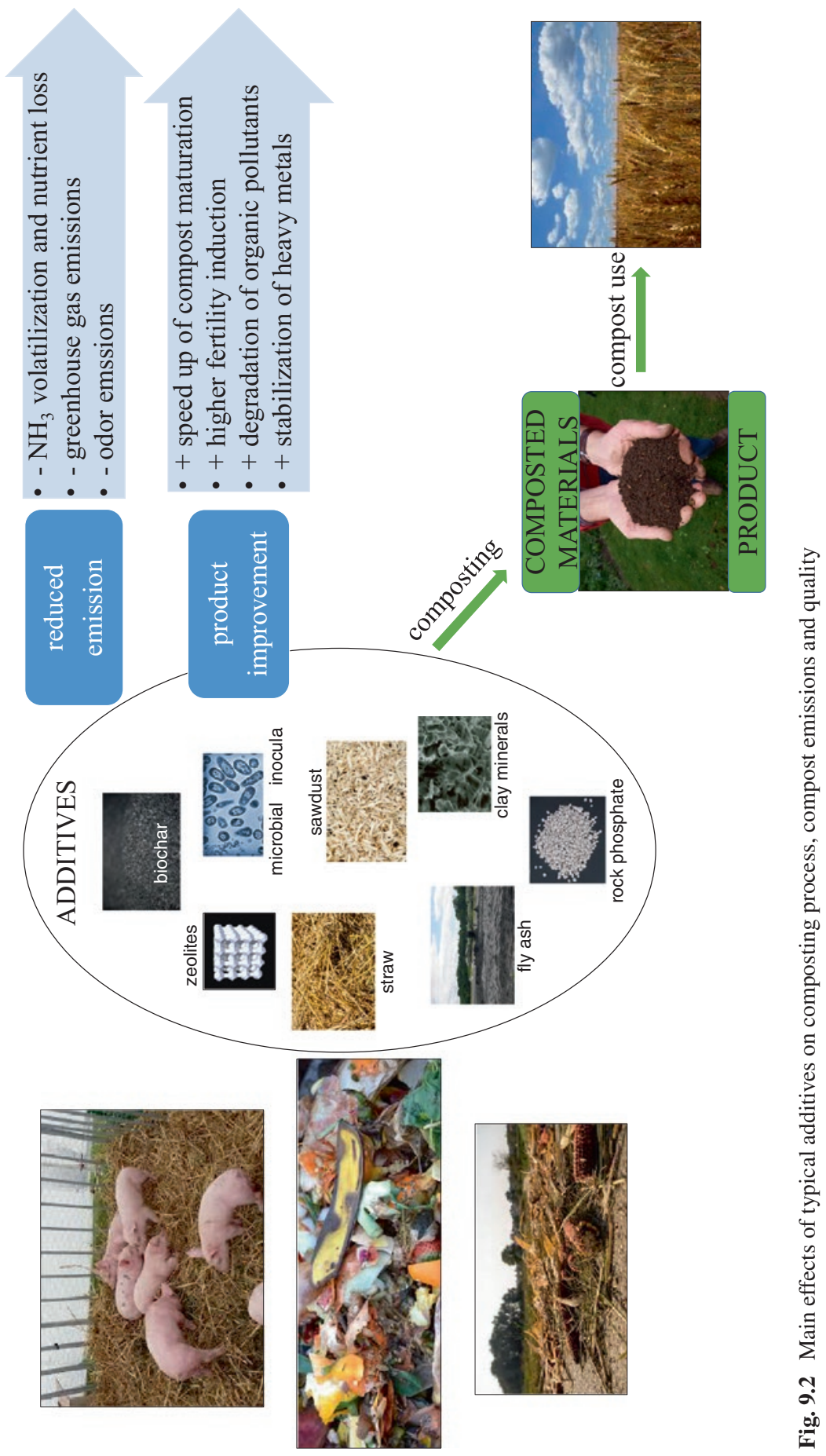


optimisation of a co-composting process is feasible, as demonstrated by the work of Cai et al. (2007), who achieved a PAH removal rate higher than $94 \%$ from sewage sludge co-composted with rice straw through suitable turning methods, controlled aeration, small addition of wood chips and the inoculation of microorganisms, enzymes and growth-promoting molecules. The achievement of high temperatures is crucial for the degradation of recalcitrant and harmful substances as it increases their solubility, making them more available to metabolism (Antizar-Ladislao et al. 2004). In regard to the timing of the co-composting processes of mixed organic and mineral waste, the work of Atagana (2004) showed that the co-composting of a mineral soil with poultry manure, with the aim of soil decontamination by PAHs, required 19 months, about four to five times the typical composting time of poultry manure alone. Similarly, in the co-composting study of Huang et al. (2016) the estimated dissipation half-life of 4-nonylphenol was reduced by 3239 to 2079 days after inoculation with the degrader strain Phanerochaete chrysosporium, and that strain inoculation enhanced the compost maturity. Another example of the optimisation of co-composting was provided by Rekha et al. (2005), who improved the process by a liming sediment pretreatment that precipitated heavy metals in low available hydroxides.

\subsection{Legislative Aspects and Implications Within the European Union}

European Parliament Resolution 97/C76/01, approved on 24 February 1997, indicated (art.35) that European Union (EU) Members States should take all possible measures to guarantee the restoration of a satisfactory level at old landfill sites or other contaminated areas, suggesting diverting waste management from landfilling to the recovery and recycling of biodegradable waste and biogas production. Over the following decades, the EU established various regulatory frameworks on waste management. The EU Waste Framework Directive (Directive 2008/98/EC), and recent revision, sets the principles of waste hierarchy in order to reduce, reuse, recycle and recover, and also strategies to minimise waste disposal. The Directive requires that prevention programmes be drawn up in order to dissociate economic growth from waste environmental impacts. EU Directive 99/31/EC requires the pretreatment of biodegradable municipal waste to reach, by 2016, a progressive reduction of $35 \%$ of biowaste landfill disposal. In spite of the fact that landfilling was not encouraged, alternative waste treatment technologies, such as composting, mechanical-biological treatments, anaerobic digestion and incineration, were not specifically suggested as alternative waste management practices. The main consequence of this feature of the EU Waste Directive was that most Member States did not immediately opt for composting or biogas production, regardless of the significant benefits from these alternative forms of waste reuse. In fact, with incineration or landfilling being still the most widespread waste management options, with a 
biowaste recycle rate ranging between $10 \%$ and $30 \%$ (Barth et al. 2008) up to the mid-2000s. Significant diversion of waste from landfilling to composting management was achieved only when waste sorting and the removal of organic waste from landfill became mandatory in European countries, although the proportion of waste sorting is still highly variable in different areas, and composting of unsorted waste is practised (e.g. in Portugal, France and some regions of Spain).

In addition to the Landfill Directive (landfill gases endangering climate) and Waste Framework Directive, other European Economic Community programmes have fuelled the development of composting activity in Europe, among them, the EU Climate Change Programme for meeting the objectives set by the Kyoto Protocol, in terms of abatement of greenhouse gas emission from all productive sectors, and the EU Soil Protection Strategy, which highlights the need to restore the fertility of agricultural soils by a significant recycle of nutrients achievable through integrated waste management and waste reuse in agriculture. Other significant EU policies influencing the composting sector are, for example, the EU Biomass Action Plan, which aims to promote energy production from biomass; the EU target for Renewable Energies, that is $20 \%$ of energy obtained from renewable sources by 2020; the EU targets on biofuels, set to $10 \%$; compulsory blending of biofuels by 2020; the EU programme for the development of rural areas; the Community Agricultural Practice; and the EU measures on soil conservation.

Regarding compost properties and quality, across EU Members standards that compost must meet in order to be qualified as products differ considerably. In some countries, such as Austria, France, Germany and Italy, the legislation clearly defines compost characteristics, whereas in other countries there is no harmonised legislation. Whether compost is classified as waste or not depends case by case on the decisions of the local regulatory authorities, and in some cases, it is implicitly assumed that compost is no longer a waste when it is registered as a product (Sayen and Eder 2014). Similarly, regulations and standards on compost quality are not equally established, with the exception of the limits set by Decision 2006/799/CE, as well as by the Animal By-Products Regulation. While the agronomic value $(\mathrm{C} / \mathrm{N}$ ratio, minimum $\mathrm{C}$ content, etc.) and contaminant presence in terms of heavy metals and inert materials are usually well established in compost quality regulations, a lack of uniformity can be recognised for the direct methods used to assess pathogen presence and phytotoxicity. The lack of harmonised legislation creates uncertainty regarding waste management decisions and limits the compost productive sector. Guidelines for the use of high-quality compost in terms of material properties, plant response tests, physical contaminants and chemical properties can be found in the European Compost Network Quality Assurance Scheme (ECN-QAS) manual (https://www.compostnetwork.info/wordpress/wp-content/uploads/180711_ECNQAS-Manual_3rd-edition_keyed-1.pdf).

In regard to the aims of this chapter, it is important to underline that, to our knowledge, the term 'co-composting' is not explicitly mentioned in any of the mentioned EU regulations, or in national or regional legislation. 


\section{A Proposal for an Improved Definition for Co-composting}

In spite of the increase in scientific interest, co-composting is still defined as the composting of organic waste in the presence of one or more organic and inorganic 'additives', generally used at low rates, with the aim of improving specific processrelated issues, such as odour emissions, quality and concentration of toxic compounds, and emission of greenhouse gases during or at the end of the composting process. Mineral, organic as well as biological additives have been shown to stimulate microbial activity, leading to an earlier start and a longer duration of the thermophilic phase as compared to regular composting. Some exceptions are considered, for example for poultry manure, which is generally recommended to be mixed at a ratio of 1:3 with lignocellulosic materials. To date, co-composting has seldom been used in the presence of 'biotic additives', such as earthworms and microbial inocula.

The term co-composting is also used when a bulking agent or wood splinters are mixed with the target organic waste to be composted. For example, composting of selected waste such as food waste bulking agents in different proportions is essential to provide a suitable structure to provide a physical habitat for the proliferation of the active microbial communities, to allow the maintenance of suitable moisture levels and to prevent anaerobic decomposition taking place. Although in some cases the bulking agents can also be used to balance the $\mathrm{C} / \mathrm{N}$ ratio of the composting mass, and to supply additional available $\mathrm{C}$ to the microorganisms active in the organic matter decomposing, this is generally not the primary scope of its use.

Here, we propose that the term co-composting should be more properly used to refer to a designed process of composting two or more organic and inorganic matrices at various rates, to reach an intended composted product, with properties suitable for its use in agriculture and the environment, as illustrated in Fig. 9.3. Therefore, the definition of co-composting should be independent of the nature and proportion of waste in the mix, because the primary aim of the co-composting process should be the transformation of the waste from the physical, chemical and microbiological point of view to achieve the formation of a designed product.

The potential of obtaining products with tailored properties through a designed co-composting process marks the difference between the use of 'additives' that can reduce emissions, improve the composting and the product quality at the end of the process in terms of nutrients content and heavy metal solubility of the end product. Several examples of scientific reports using the term 'co-composting' are reported below. In principle, it should apply for the bulking agent, which may predominate in the composting mass in some cases, for example up to two-thirds in the composting of food waste (Eftoda and McCartney 2004). Although this may be altered during the process, bulking agents are generally used to improve the decomposition of the target organic waste. The design of co-composting should rely on the control of the main physico-chemical parameters, such as temperature and the duration of the thermophilic phase, change of the $\mathrm{pH}$ and salinity values, the contribution of macronutrient and micronutrients of the matrices used for the co-composting process, the concentration and speciation of organic and inorganic pollutants, changes in the 


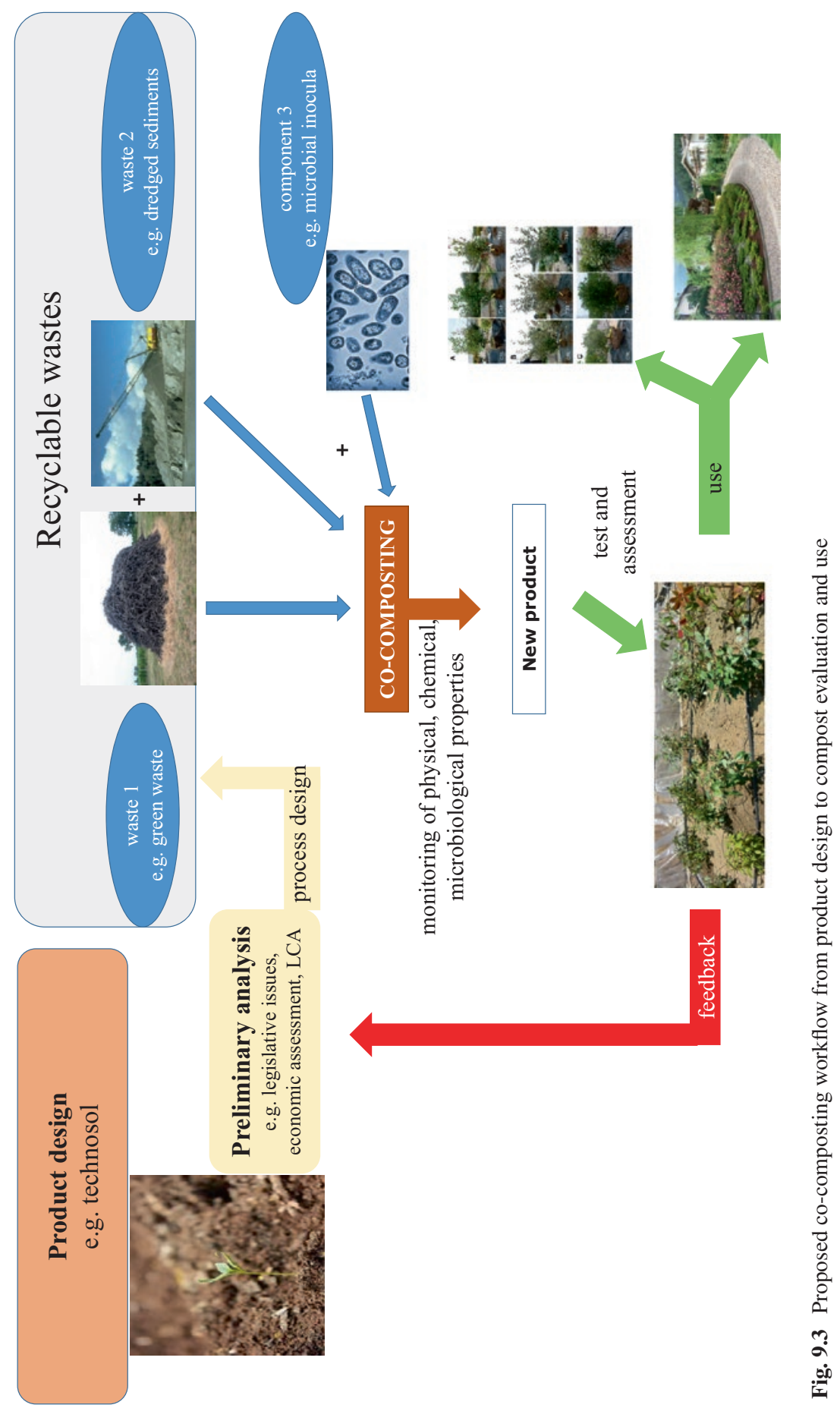


moisture content, and evolution of the microbial consortia during the entire cocomposting process. Relying on this definition of co-composting, the eventual positive effects of the designed co-composting process on the environment related to greenhouse gas abatement, use of fossil fuel-derived materials, minimisation of waste landfilling, even if pursued, should not be the primary objectives of the designed process. In fact, while it has been reported that the biological, organic and mineral additives can significantly improve the compost process, this will result in the same end product of the waste under the composting process. By contrast, a cocomposting process should lead to a final material with significantly different properties from the original, and with suitable properties for a specific intended use.

Below, we provide a practical example of this approach in a case study of the co-composting of sediments with green waste for their conversion into a technosol for plant nursery activities.

\section{Co-composting of Dredged Sediments with Green Waste to Produce Technosols: A Pilot Study}

A pilot project conducted in Italy by the authors of this chapter is presented here to show the usefulness, as well as the challenges, of the improved definition of cocomposting presented in Sect. 2. In this section, we present a case study of the cocomposting of sediments and green waste to produce fertile technosol and growing media suitable for a plant nursery. While the composting of green waste is a widespread practice, the use of dredged sediments for a co-composting process is still problematic, for several reasons, such as legislative ones, as mentioned above. In fact, in Italy, dredged sediments are currently classified as waste, regardless of their degree of contamination, and their use as soil amendment or an ingredient in growing media is not officially permitted.

In the presented case study, we demonstrated that the use of unpolluted brackish sediments co-composted with green waste from pruning of public and private green areas can produce fertile technosols and growing media, with no potential ecological risks. The case study aimed to demonstrate the suitability of dredged sediments co-composted with green waste to produce innovative growing media for plant nurseries and amendment for restoration of degraded soils. The performance of the novel sediment-based growing media was compared with that of typical peat-based growing media. The presented case study also highlights how some restrictions in the current legislation prevent the integrated management of different waste categories in co-composting treatments, regardless of their pollution levels. 


\subsection{Materials and Methods}

Sediments (S) were dredged from the Navicelli canal (Pisa, Central Italy, $\left.43^{\circ} 38^{\prime} 32.9^{\prime \prime} \mathrm{N}, 10^{\circ} 21^{\prime} 19.4^{\prime \prime} \mathrm{E}\right)$, a commercial $17 \mathrm{~km}$-long channel connecting the city of Pisa to the coast that hosts numerous industrial activities. Analysis of freshly dredged sediments showed an average concentration of PAHs of $1.36 \mathrm{mg} / \mathrm{kg} \mathrm{dw}$, slightly exceeding the limit $(1.00 \mathrm{mg} / \mathrm{kg})$ set by Italian legislation. After dredging, sediments were allowed to dry inshore in the Navicelli area for 2 months prior to sampling, and $2 \mathrm{~m}^{3}$ of sediments were collected from the surface layer $(0-30 \mathrm{~cm})$ of the sediment pile, crumbled and further air-dried. Fresh pruning waste $(\mathrm{GW})$, consisting of mixed tree branches collected from public and private green areas, obtained from the waste management organisation of the city of Florence, were shredded and used within 3 days of collection. The co-composting experiment was conducted using $0.200 \mathrm{~m}^{3}$ volume cylindrical composters and four treatments were tested: sediments only (S), GW only (GW), 1:1 w:w S:GW (SGW1:1) and 3:1 w:w $\mathrm{S}: \mathrm{GW}$ (SGW3:1). All treatments were prepared in three replicates arranged in a completely randomised block design. Composters were left outdoors from June 2014 to March 2015, and tap water was added only at the beginning of the cocomposting process, and on sampling occasions for the analysis of leachates. The composting materials were manually mixed after $1,2,3$ and 6 months of composting to homogenate to allow for the optimal completion of the co-composting process. All composting materials were regularly checked for temperature and moisture content, and every 3 months subsamples were taken for the analysis of total and organic carbon and total nitrogen, and for the content of humic acids (HA) and fulvic acids (FA), to determine the humification index (HA/FA ratio). Bulk density was calculated by the weight/volume ratio of an undisturbed sample after drying at $105^{\circ} \mathrm{C}$ until constant weight. Concentrations of heavy metals and PAHs were analysed by inductively coupled plasma-optical emission spectroscopy, and by extraction with acetone and hexane mixture, followed by gas chromatography-mass spectrometry (GC/MS) determination. Full details of the co-composting preparation and analytical methodologies were reported by Mattei et al. (2016). At maturity, the co-composted and parent materials were evaluated for their main physico-chemical properties, eco-toxicity, microbial activity and diversity, and fertility, and details of these aspects were reported by Mattei et al. (2017).

The results of this pilot experiment show that, notwithstanding the fact that the co-composting materials underwent an initial short and moderate thermophilic phase, resulting in a cold composting process, both the SGW3:1 and SGW1:1 products had physical and chemical properties that complied with the quality guidelines for growing media in terms of total organic $\mathrm{C}, \mathrm{N}$ and humification index, $\mathrm{pH}$ and electrical conductivity, and bulk density values (Fig. 9.4). Interestingly, the PAHs concentration in SGW3:1 and SGW1:1 were reduced by $26 \%$ and 57\%, respectively, up to concentrations below $1 \mathrm{mg} \mathrm{kg}^{-1}$, confirming that co-composting of sediment with green waste is a suitable approach for producing plant-growing 


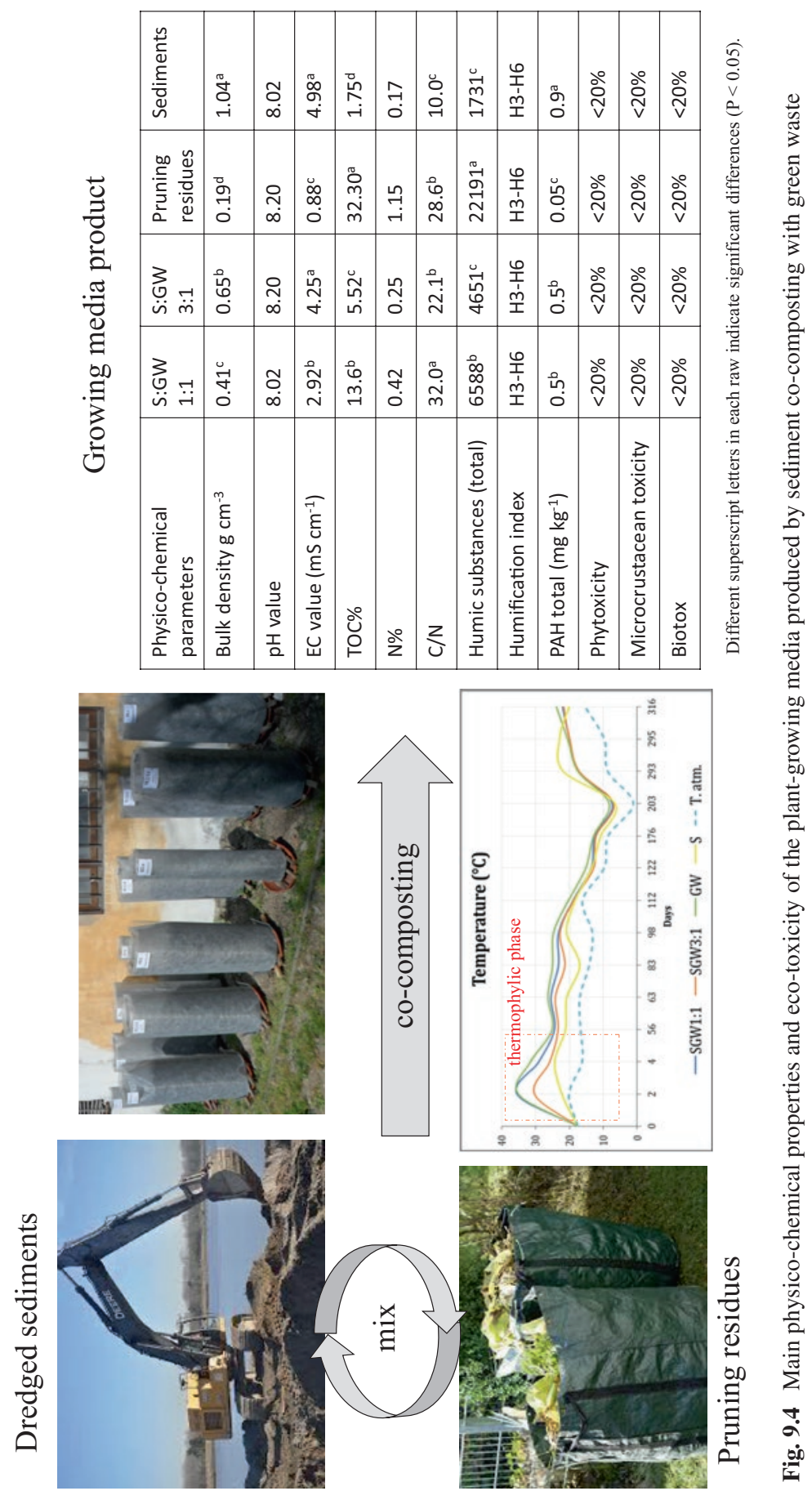


media with optimal characteristics, and also eventually degrades organic pollutants (Fig. 9.4).

Results of the eco-toxicity, microbial diversity and performance of sediment in the sediment-based growing media co-composted with the green waste as growing medium for ornamental plants showed that the co-composted materials increased the diversity of bacteria, fungi and archaea, as compared to the sediment alone, had no ecotoxicological impacts on microorganisms, micro-invertebrates and plants, evaluated with the Biotox test (Lappalainen et al. 2001), Daphnia magna mortality and immobilisation test (ISO 6341:1996), and the phytotoxicity test (ISO 11269-1:2012), respectively. Moreover, the co-composted material allowed an optimal growth of the ornamental plants of prime interest for the local market, Photina $\mathrm{x}$ fraseri and Viburnum tinum.

The tested treatment also increased the speed of degradation of PAHs in the slightly polluted sediments, and a decrease of salinity was a key factor in enabling an effective organic matter and PAHs degradation by the microbial community (Fig. 9.5). An important aspect was that co-composting reduced the sediment bulk density, enhancing sediment aeration and permeability, to enrich the sediment with $\mathrm{N}$ and humic substances, and to increase microbial biodiversity.

Co-composting of dredged material with green waste proved to be a sustainable and effective treatment to convert the two waste materials into a growing medium with no eco-toxicity and high fertility (Fig. 9.5).

\subsection{Key Observations}

A limiting factor in the use of the co-composting process as a remediation technique is the possible presence of heavy metals in raw matrices, as they tend to concentrate during the composting process, compromising or limiting the possible reuse of the finished product. In the presented case study, the concentrations of heavy metals in the co-composted sediments were all below the Italian legislation limits on growing media (Legislative Decree 75/2010) and eco-toxicity, and plant elemental concentrations did not show effects attributable to excessive heavy metals availability. However, the novel sediment-based growing media have no corresponding materials in the Italian legislation, nor in European legislation, because sediments are not currently admitted as ingredients of growing media, and therefore a comparison with the materials currently admitted in Italian legislation is not straightforward. The initial nutrients content of sediments and green waste, and the formation of a physical microstructure improving the water retention, were the main factors inducing fertility in the sediment-based growing media. These fundamental fertility factors provide an edge over the peat- and coconut fibre-based growing media, allowing plant nursery with reduced nutrient contents and alleviating water use, which has worsened in the EU, particularly in the Mediterranean area. The devised cocomposting process appeared to be in line with the major EU initiatives to reduce environmental impact and soil loss, developing innovative management options for 

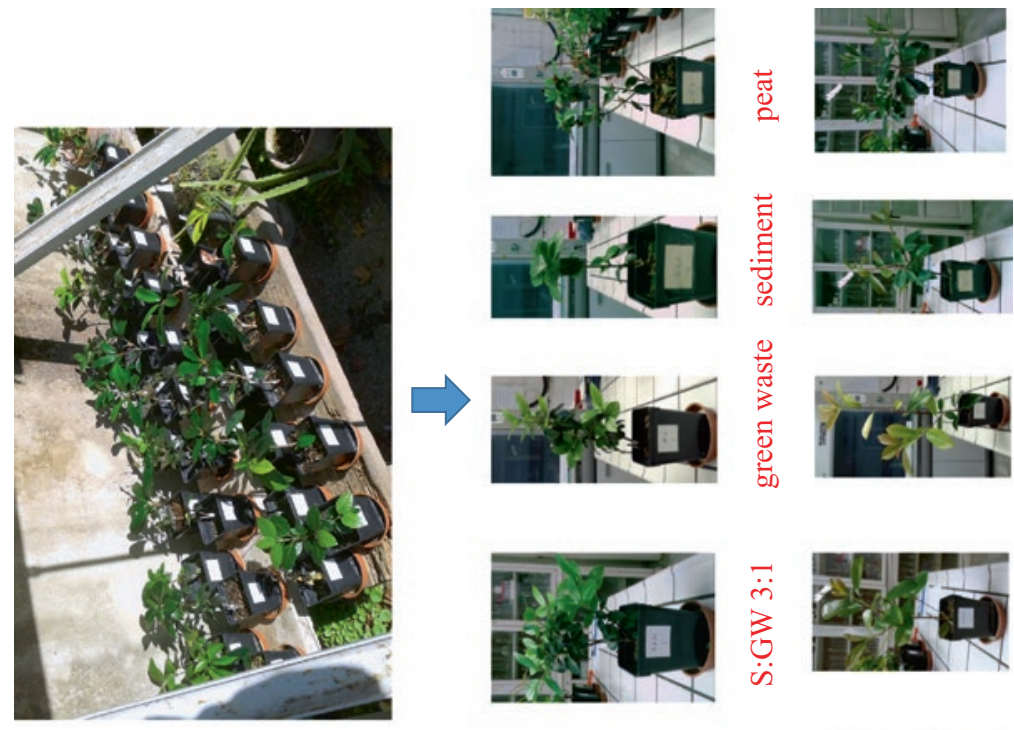

荘
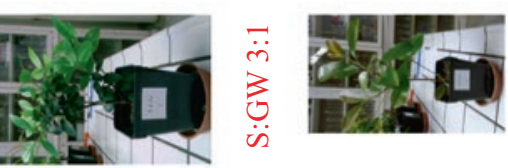

ن

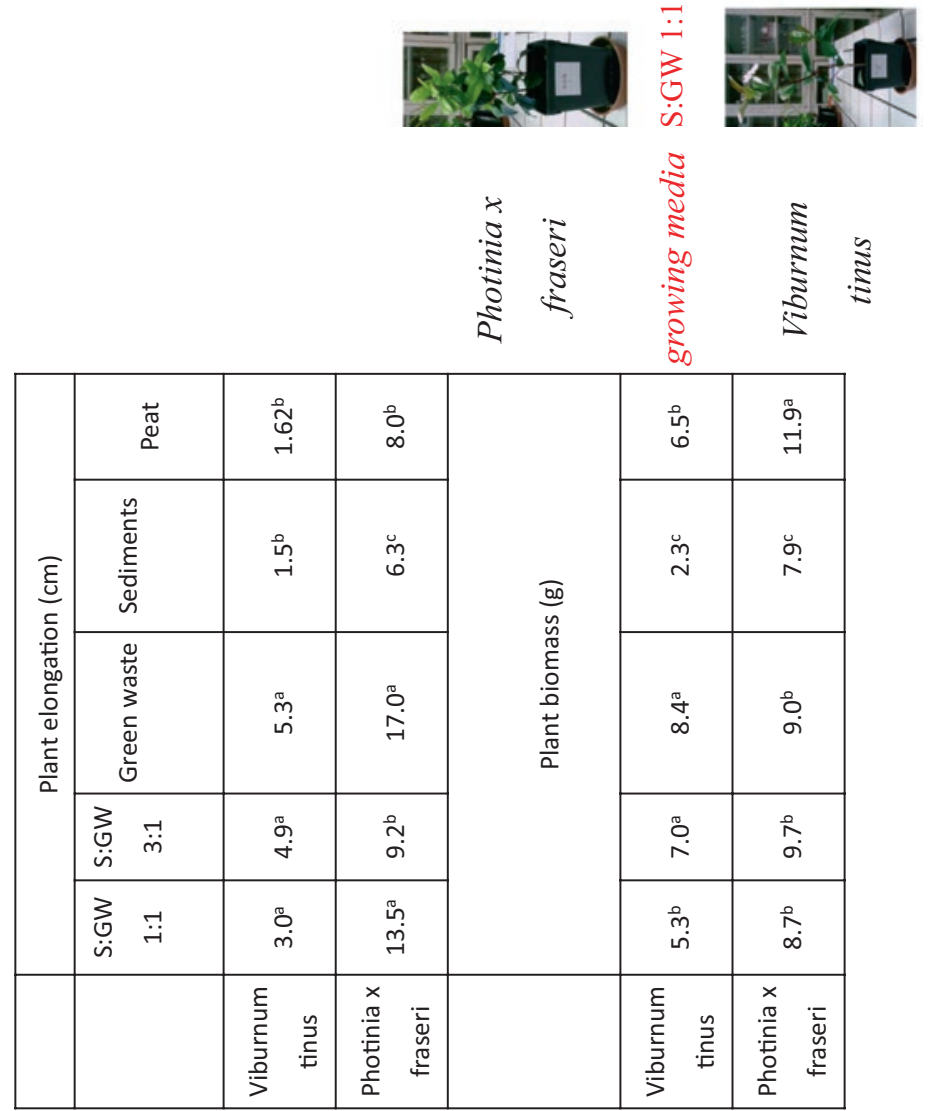

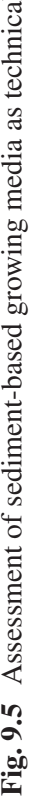


dredged sediments and pruning residues, two relevant waste categories for various EU Countries. The results are in line with the objectives of soil protection illustrated in the EU Commission Report (COM 2012), which argues that the use of sediments co-composted with green waste should be seen as a strategy to achieve a 'land degradation-neutral world'. Implementation of this new technology at commercial scale is in line with the emission reduction targets from the agricultural sector, prevention of soil degradation and restoration of degraded soils, and the recycling of nutrients. Therefore, the results of the case study are also in line with the EU thematic Strategy on Waste Prevention and Recycling, within the frame of the abovementioned Directive 2008/98/EC, which emphasises on the need to go for an appropriate legislative proposal based on biowaste quality parameters. Sustainable and effective management of our resources in closed loops will become the key factor for the future.

An important feature in recycling waste through co-composting is the time necessary to obtain a reclaimed and fertile product. A scaling up of the devised cocomposting process in wide piles and windrows, also complemented with other low-impact technologies, such as bioaugmentation, so as to increase the temperature and prolong the thermophilic phase to reduce the maturation time and further increase the stability of the final product, is currently being tested within the ambit of the EU project AGRISED (LIFE17-ENV_IT_000269).

\subsection{Legislative Issues Relating to Two Types of Waste - One Product Scenario}

All EU Directives, national regulations and international conventions indicate that dredged materials should be primarily considered as natural resources that should be recycled when not flown back to their original sites. However, the current environmental legislation poses potential conflicts between EU Directives and international conventions, particularly in defining dredged materials as waste or a natural resource, with no definite solution, particularly as regards the possibility of the reuse of dredged sediments as by-products in agriculture or in composting processes. Consequently, different European countries still rely on national legislations or regulations by local authorities. While for marine sediments the London Convention has priority over EU legislation, for dredged materials from inland water bodies the decision is merely local, generating administrative stack and increased management costs. Therefore, clarification of the legislation on the possibility of using dredged sediments as components of growth media for ornamental plants, after proper testing of human and environmental safety, may lead to allowing the EU-wide use of reclaimed sediments in agriculture, particularly for the cultivation of ornamental plants and as amendment for the reclamation of degraded soils. Concerning pruning residues management, currently, the EU produces on average 13 million tonnes of 
wood pruning residues from various sources, with only a minor fraction used as energy biomass (GREENOVATE 2018). Although forestry and milling waste is already used for producing pellets and woodchips, pruning residues have limited use potential due to their variable and composite quality, as compared to other plant biomass (e.g. energy crops). The lack of systematic reuse of pruning residues and their remaining outside of the bioenergy market give rise to sustainability concerns. Pruning waste is treated as a plant biomass resource or as a waste. More rarely, pruning waste is shredded and left on the soil to act as a soil fertiliser or conditioner, or more rarely it is used by the farmer as firewood for self-consumption. In most cases, pruning residues are removed to prevent phytosanitary problems and have limited value as fertilisers, as they mostly present high $\mathrm{C} / \mathrm{N}$ ratio values, leading to $\mathrm{N}$ immobilisation in soil, aggravating the low $\mathrm{N}$ use efficiency of most crops. There is currently no suitable large-scale value chain for pruning residues across the EU, which are commonly managed across multiple collection sites at local scale, mainly composted or landfilled. There is also uncertainty on the amount of pruning residues actually used to produce energy in the EU, because the current EUROSTAT (2014) category 'other vegetal materials and residues' includes biomass not specified elsewhere, such as straw, vegetable husks, ground nut shells, pruning brushwood, olive pomace and other waste arising from the maintenance, cropping and processing of plants. It is estimated that in Mediterranean countries orchards produce on average 2.5 tonnes of pruning residues per hectare per year, and the Czech Republic and Italy, where the HORTISED demonstration trials will be conducted, are by far the EU countries producing the highest amounts of pruning residues, with an annual production of ca. 7.8 and 5.2 million tonnes per year, respectively (GREENOVATE 2018). There is clear evidence of the impact caused by the lack of management of pruning residues in the $\mathrm{EU}$, and their reuse is in line with the need to increase renewable energy to meet the 2020 climate and energy targets. The use of pruning biomass can be encouraged if their role in innovative technologies can be demonstrated, and although pruning residues are considered of low quality, they can be used to reclaim dredged sediments through a co-composting process (Mattei et al. 2016). This technological approach can stimulate the establishment of a business model that successfully takes account of the labour intensity of pruning collection and transportation, particularly in relation to the demand for growing media for plant nurseries, amendments to restore the fertility of degraded soils, and technosols for the maintenance of urban green obtained by co-composting of sediment and pruning residues. Farms have expressed an interest in changing the destination of pruning residues, particularly towards a practical and cheap recovery, suitable to allow their recycle in agriculture. The use of a significant proportion of pruning residues for the production of sediment-based growing media, soil amendment and technosols by well-designed co-composting protocols can contribute to compliance with National Renewable Energy Action Plans of the EU Member States, and also reduce the open-air burning of pruning residues, which cause environmental problems, such as the release of fumes and micro-particulate pollutants in the atmosphere. 


\section{Discussion}

Overall, the results of the above-illustrated pilot experiment confirmed the potential reclamation of sediment through a proper design of a co-composting process with green waste, in line with the results previously obtained by Macía et al. (2014). Monitoring of PAH concentration during the co-composting process also confirmed the potential of this approach to remediate eventual high concentrations of organic pollutants, confirming previously published observations (Aparna et al. 2008; Cai et al. 2007; Huang et al. 2016; Rekha et al. 2005). The adopted co-composting approach can also contribute to a better management of the pruning residues produced by the management of green urban areas. In fact, notwithstanding the fact that the most recent EU Directive 2015/1185 (implementing Directive 2009/125/EC) and Regulation (EU) 2015/1189 also encourage the reuse of pruning residues, it is estimated that in Italy more than $80 \%$ are landfilled due to the unfavourable costs of their energy rating, that is the ratio between the pruning residues' net calorific value and the impact and costs of transportation (EBS 2019). Furthermore, pruning residues from the urban areas can be polluted by heavy metals and organic xenobiotics that prevent their direct use as soil amendment, and can result in low-grade compost.

Owing to the potential matter and energy recycling, the composting of waste materials is a non-replaceable technological approach to waste management for all human societies, independent of the degree of development (Hoornweg et al. 2013), and properly designed co-composting can enhance the sustainable management of various waste types, through the creation of a new product downstream of the process. To achieve this goal, nutrients present in the waste blends and formation of a suitable physical structure in the products can be a priori designed to fulfil specific technical demands. However, notwithstanding the ever-increasing interest in compost science, the progress in the testing of various materials and conditions, and the use of more sensitive analytical techniques to identify the main chemical mechanisms involved in compost maturation and their final properties, most of the cited works have been carried out at bench, vessel or pilot scale. The outcome of the pilot experiment reported on in this chapter will be confirmed through a scaling up at industrial level during the demonstration phase of the LIFE AGRISED project (http://www.lifeagrised.com). Overall, the obtained results indicate that a more systematic adoption of a co-composting process may provide a 'win-win' option for the integrated management of dredged sediments and pruning residues in a short supply chain, as growing media, soil amendment and technosols might be locally used, thus creating a potential development of value chain at local level.

\subsection{Technical Mismatch and Legislative Gaps}

Concerning the technical mismatch and sustainability issues, we notice that interesting results in regard to the control of the maturation process, nutrient retention and greenhouse gas emissions during the composting of organic waste were obtained 
using additives that are seldom available in different areas where composting is a practical solution for the management of organic waste. For example, are suitable amounts of clay and Fe-Al-bearing minerals commonly available in rural areas? Biochar amendment appears to be a promising additive that can effectively reduce the emissions from composting waste and stabilise the heavy metals in the final compost. Even in developed countries, is pyrolysis technology sufficiently widespread to ensure sufficient amounts of biochar for the composting industry? Moreover, because, if they are available the same additives are often requested by other industrial processes, at what cost can they be obtained by the compost industry?

In our experience, there are still limitations that apply to both the legislative and shared knowledge aspects. However, while limitations caused by poor information on new technologies can be alleviated by access to digital multimedia and dedicated communication channels between scientists and stakeholders, legislative limitations are slower to surmount, as they are related to the political agenda of different countries. For example, this is well illustrated by the case of biochar, which is officially admitted as a fertiliser or soil conditioner in some countries (e.g. Italy), but not in several others. Therefore, all the positive results related to the use of biochar can be taken advantage of only where biochar is officially permitted under the environmental and agricultural legislation. In the case of dredged sediments, while they can be employed in several civil engineering uses, their use is not permitted in agriculture, and from the legislative point of view limiting the presence of sediments in the finished product may limit their use in agriculture. Therefore, it is not clear that cocomposted sediments can be used as fertilisers or soil amendments. These legislative discrepancies limit the use of innovative co-composting approaches, both at production and commercial levels.

\section{Conclusions}

In our opinion, the 'compost community' can substantially contribute to the minimisation of the environmental impact of the waste cycle and the maximisation of materials and energy recycling by demonstrating the possible upscaling of the most promising approaches developed at the microscale. We identified two main reasons for hindrance in our literature survey, which we termed (i) technical mismatch and sustainability issues, and (ii) legislative and knowledge gaps. We envisage even greater difficulties in the case of co-composting as we defined it in this chapter, that is the designed mixing of different types of waste to obtain new products. In this case major changes will be needed to allow the use of co-composted materials obtained by diverse sources, and clear and broad dissemination of knowledge, through the scientific and popular press, will be essential to obtain public acceptance of the innovative processes and materials. 
Acknowledgement This work was supported by the EU project AGRISED (LIFE17-ENV_ IT_000269).

\section{References}

AGRISED Project, LIFE17-ENV_IT_000269. EASME, European Commission, Brussels, Belgium.

Antizar-Ladislao, B., Lopez-Real, J. M., \& Beck, A. J. (2004). Bioremediation of polycyclic aromatic hydrocarbon $(\mathrm{PAH})$-contaminated waste using composting approaches. Environmental Science and Technology, 34, 249-289.

Aparna, C., Saritha, P., Himabindu, V., \& Anjaneyulu, Y. (2008). Techniques for the evaluation of maturity for composts of industrially contaminated lake sediments. Waste Management, 28, $1773-1784$.

Atagana, H. I. (2004). Co-composting of PAH-contaminated soil with poultry manure. Letters in Applied Microbiology, 39, 163-168.

Awasthi, M. K., Wang, Q., Chen, H., Wang, M., Awasthi, S. K., Ren, W., Cai, H., Li, R., \& Zhang, Z. (2016). In-vessel co-composting of biosolid: Focusing on mitigation of greenhouse gases emissions and nutrients conservation. Renewable Energy, 129, 814-823.

Barth, J., Amlinger, F., Favoino, E., Siebert, S., Kehres, B., Gottschall, R., Bieker, M., Löbig, A., \& Bidlingmaier, W. (2008). Compost production and use in the EU. Final report. European Commission, DG Joint Research Centre/ITPS.

Barthod, J., Rumpel, C., Paradelo, R., \& Dignac, M.-F. (2016). The effects of worms, clay and biochar on $\mathrm{CO} 2$ emissions during production and soil application of CO-composts. The Soil, 2, 673-683.

Barthod, J., Rumpel, C., \& Dignac, M. F. (2018). Composting with additives to improve organic amendments. A review. Agronomy for Sustainable Development, 38(2), 17.

Belyaeva, O. N., \& Haynes, R. J. (2009). Chemical, microbial and physical properties of manufactured soils produced by co-composting municipal green waste with coal fly ash. Bioresource Technology, 100, 5203-5209.

Bentham, R., \& McClure, N. (2003). A novel laboratory microcosm for co-composting of pentachlorophenol contaminated soil. Compost Science and Utilization, 11, 311-320.

Bernal, M. P., Navarro, A. F., Sanchez-Monedero, M. A., Roig, A., \& Cegarra, J. (1998). Influence of sewage sludge compost stability and maturity on carbon and nitrogenmineralization in soil. Soil Biology Biochemistry, 30, 305-313.

Bernal, M. P., Alburquerque, J. A., \& Moral, R. (2009). Composting of animal manures and chemical criteria for compost maturity assessment. A review. Bioresource Technology, 100, 5444-5453.

Bernstad, A., \& la Cour Jansen, J. (2011). A life cycle approach to the management of household food waste - a Swedish full-scale case study. Waste Management, 31, 1879-1896.

Bolan, N. S., Kunhikrishnan, A., Choppala, G. K., Thangarajan, R., \& Chung, J. W. (2012). Stabilization of carbon in composts and biochars in relation to carbon sequestration and soil fertility. Science of the Total Environment, 424, 264-270.

Büyüksönmez, F., Rynk, R., Hess, T. F., \& Bechinski, E. (1999). Occurrence, degradation, and fate of pesticides during composting. I. Composting, pesticides, and pesticide degradation. Compost Science and Utilization, 7, 66-82.

Cai, Q. Y., Mo, C. H., Wu, Q. T., Zeng, Q. Y., Katsoyiannis, A., \& Férard, J. F. (2007). Bioremediation of polycyclic aromatic hydrocarbons (PAHs)-contaminated sewage sludge by different composting processes. Journal of Hazardous Materials, 142, 535-542.

Chen, Y. X., Huang, X. D., Han, Z. Y., Huang, X., Hu, B., Shi, D. Z., \& Wu, W. X. (2010). Effects of bamboo charcoal and bamboo vinegar on nitrogen conservation and heavy metals immobility during pig manure composting. Chemosphere, 78, 1177-1181. 
Choi, K. (1995). Optimal operating parameters in the composting of swine manure with wastepaper. Journal of Environmental Science and Health, 34, 975-987.

Chowdhury, M. A., de Neergaard, A., \& Jensen, L. S. (2014). Potential of aeration flow rate and bio-char addition to reduce greenhouse gas and ammonia emissions during manure composting. Chemosphere, 97, 16-25.

COM. (2012). Convergence report 2012 - European Economy 3|2012. European Commission Directorate-General for Economic and Financial Affairs.

Czekała, W., Malinska, K., Cáceres, R., Janczak, D., Dach, J., \& Lewicki, A. (2016). Co-composting of poultry manure mixtures amended with biochar - The effect of biochar on temperature and C-CO2 emission. Bioresource Technology, 200, 921-927.

Decision 2006/799/CE. Establishing revised ecological criteria and the related assessment and verification requirements for the award of the Community eco-label to soil improvers. Official Journal of the European Union 24.11.2006.

Directive 2008/98/EC. On waste and repealing certain Directives. Official Journal of the European Union L 312/3.

Directive 2009/125/EC. Establishing a framework for the setting of eco-design requirements for energy-related products. Official Journal of the European Union 31.10.2009.

Directive 99/31/EC. On the landfill of waste. Council Directive Official Journal of the European Union L 182/1.

EBS. (2019). Italian Association of solid biomass. Primo Rapporto Socio Economico e Ambientale.

Eftoda, G., \& McCartney, D. (2004). Determining the critical bulking agent requirement for municipal biosolids composting. Compost Science and Utilization, 12, 208-218.

Englert, C. J., Kenzie, E. J., \& Dragun, J. (1993). Bioremediation of petroleum products in soil. In E. J. Calabrese \& P. T. Kostecki (Eds.), Principles and practices for petroleum contaminated soils (pp. 111-130). Boca Raton, FL: Lewis Publishers.

European Parliament Resolution 97/C76/01. (11/03/1997). A Community strategy for waste management. Official Journal C 076, 0001-0004.

Eurostat. (2014). Waste statistics. Statistics explained.

Fan, C., \& Tafuri, A. N. (1994). Engineering applications of biooxidation processes for treating petroleum contaminated soil. In D. L. Wise \& D. J. Trantolo (Eds.), Remediation of hazardous waste contaminated soils (pp. 373-406). New York: Marcel Dekker.

GREENOVATE. (2018). Mobilising pruning residues to expand Europe's biomass market. Euro Pruning, GREENOVATE annual report.

Guangwei, Y., Hengyi, L., Tao, B., Zhong, L., Qiang, Y., \& Xianqiang, S. (2009). In-situ stabilisation followed by ex-situ composting for treatment and disposal of heavy metals polluted sediments. Journal of Environmental Science, 21, 877-883.

Hao, X., Larney, F. J., Chang, C., Travis, G. R., Nichol, C. K., \& Bremer, E. (2005). The effect of phosphogypsum on greenhouse gas emissions during cattle manure composting. Journal of Environmental Quality, 34, 774-781.

Hoornweg, D., Thomas, L., \& Otten, L. (2000). Composting and its applicability in developing countries. (Urban waste management working paper series no. 8). Washington, DC: The World Bank.

Hoornweg, D., Bhada-Tata, P., \& Kennedy, C. (2013). Environment: Waste production must peak this century. Nature, 502, 615-617.

Huang, D., Qin, X., Xu, P., Zeng, G., Peng, Z., Wang, R., Wan, J., Gong, X., \& Xue, W. (2016). Composting of 4-nonylphenol-contaminated river sediment with inocula of Phanerochaete chrysosporium. Bioresource Technology, 221, 47-54.

ISO 11269-1:2012. Soil quality - Determination of the effects of pollutants on soil flora - part 1: method for the measurement of inhibition of root growth.

ISO 6341:1996. Water quality - determination of the inhibition of the mobility of Daphnia magna Straus (Cladocera, Crustacea) - Acute toxicity test.

Khan, N., Clark, I., Sánchez-Monedero, M. A., Shea, S., Meier, S., \& Bolan, N. (2014). Maturity indices in co-composting of chicken manure and sawdust with biochar. Bioresource Technology, $168,245-251$. 
Kuba, T., Tschöll, A., Partl, C., Meyer, K., \& Insam, H. (2008). Wood ash admixture to organic wastes improves compost and its performance. Agriculture, Ecosystems and Environment, 127, 43-49.

Laine, M. M., \& Jorgensen, K. S. (1997). Effective and safe composting of chlorophenol contaminated soil in pilot scale. Environmental Science and Technology, 31, 371-378.

Lappalainen, J., Juvonen, R., \& Nurmi, J. (2001). Automated color correction method for Vibrio fischeri toxicity test. Comparison of standard and kinetic assays. Chemosphere, 45, 635-641.

Lefcourt, A. M., \& Meisinger, J. J. (2001). Effect of adding alum or zeolite to dairy slurry on ammonia volatilization and chemical composition. Journal of Dairy Science, 84, 1814-1821.

Legislative Decree 75/2010. Riordino e revisione della disciplina in materia di fertilizzanti. Official Journal of Laws and Decrees of the Italia Republic (GU Serie Generale - Suppl. Ordinario $\mathrm{n}$. 106) n.121.

Liang, C., Das, K. C., \& McClendon, R. W. (2003). The influence of temperature and moisture contents regimes on the aerobic microbial activity of a biosolids composting blend. Bioresource Technology, 86, 131-137.

Ling, C. C., \& Isa, M. H. (2006). Bioremediation of oil sludge contaminated soil by co-composting with sewage sludge. Journal of Scientific \& Industrial Research, 65, 364-369.

Lu, D., Wang, L., Yan, B., Ou, Y., Guan, J., Bian, Y., \& Zhang, Y. (2014). Speciation of Cu and $\mathrm{Zn}$ during composting of pig manure amended with rock phosphate. Waste Management, 34, $1529-1536$.

Macía, P., Fernández-Costas, C., Rodríguez, E., Sieiro, P., Pazos, M., \& Sanromán, M. A. (2014). Technosols as a novel valorization strategy for an ecological management of dredged marine sediments. Ecological Engineering, 67, 182-189.

Mattei, P., Cincinelli, A., Martellini, T., Natalini, R., Pascale, E., \& Renella, G. (2016). Reclamation of river dredged sediments polluted by PAHs by co-composting with green waste. Science of the Total Environment, 567-574.

Mattei, P., Roberta Pastorelli, R., Rami, G., Mocali, S., Giagnoni, L., Gonnelli, C., \& Renella, G. (2017). Evaluation of dredged sediment co-composted with green waste. Journal of Hazardous Materials, 333, 144-153.

Maulini-Duran, C., Artola, A., Font, X., \& Sánchez, A. (2014). Gaseous emissions in municipal wastes composting: Effect of the bulking agent. Bioresource Technology, 172, 260-268.

Namkoong, W., Hwang, E. Y., Parka, J. S., \& Choi, J. Y. (2001). Bioremediation of dieselcontaminated soil with composting. Environmental Pollution, 119, 23-31.

Nishanth, D., \& Biswas, D. R. (2008). Kinetics of phosphorus and potassium release from rock phosphate and waste mica enriched compost and their effect on yield and nutrient uptake by wheat (Triticum aestivum). Bioresource Technology, 99, 3342-3353.

Regulation (EU) 2015/1189. Commission Regulation (EU) 2015/1185 With regard to ecodesign requirements for solid fuel local space heaters. Official Journal of the European Union L 193/1.

Rekha, P., Suman Raj, D. S., Aparna, C., Hima Bindu, V., \& Anjaneyulu, Y. (2005). Bioremediation of contaminated lake sediments and evaluation of maturity indices as indicators of compost stability. International Journal of Environmental Research and Public Health, 251-262.

Ren, L., Schuchardt, F., Shen, Y., Li, G., \& Li, C. (2009). Impact of struvite crystallization on nitrogen losses during composting of pig manure and cornstalk. Waste Management, 30(5), 885-892.

Sayen, H., \& Eder, P. (2014). End-of-waste criteria for biodegradable waste subjected to biological treatment (compost \& digestate): Technical proposals (p. 308). Luxembourg: European Commission EUR 26425 - Joint Research Centre - Institute for Prospective Technological Studies, Publications Office of the European Union.

Shao, L. M., Zhang, C. Y., Wu, D., Lü, F., Li, T. S., \& He, P. J. (2014). Effects of bulking agent addition on odorous compounds emissions during composting of OFMSW. Waste Management, 34, 1381-1390.

Steiner, C., Das, K. C., Melear, N., \& Lakly, D. (2010). Reducing nitrogen loss during poultry litter composting using biochar. Journal of Environmental Quality, 39, 1236-1242. 
UNEP-CalRecovery. (2005). Solid waste management. Report to Division of Technology, Industry, and Economics, International Environmental Technology Centre, United Nations Environmental Programme, Osaka, Japan- CalRecovery, Inc., California, USA, p. 525.

Venglovsky, J., Sasakova, N., Vargova, M., Pacajova, Z., Placha, I., Petrovsky, M., \& Harichova, D. (2005). Evolution of temperature and chemical parameters during composting of the pig slurry solid fraction amended with natural zeolite. Bioresource Technology, 96, 181-189.

Wan, C. K., Wong, J. W. C., Fang, M., \& Ye, D. Y. (2003). Effects of organic wastes amendments on degradation of PHAs using thermophilic composting. Environmental Technology, $24,23-30$.

Wang, J., Hu, Z., Xu, X., Jiang, X., Zheng, B., Liu, X., Pan, X., \& Kardol, P. (2014). Emissions of ammonia and greenhouse gases during combined precomposting and vermicomposting of duck manure. Waste Management, 34, 1546-1552.

Waquas, M., Nizami, A. S., Aburiazaiza, A. S., Barakat, M. A., Ismail, I. M. I., \& Rashid, M. I. (2018). Optimization of food waste compost with the use of biochar. Journal of Environmental Management, 216, 70-81.

Wei, Z., Xi, B., Zhao, Y., Wang, S., Liu, H., \& Jiang, Y. (2007). Effect of inoculating microbes in municipal solid waste composting on characteristics of humic acid. Chemosphere, 68, 368-374.

Yang, F., Xue, G., Qing, L., Yang, Y., \& Luo, W. H. (2013). Effect of bulking agents on maturity and gaseous emissions during kitchen waste composting. Chemosphere, 93, 1393-1399.

Zhang, L., \& Sun, X. (2014). Changes in physical, chemical, and microbiological properties during the two-stage co-composting of green waste with spent mushroom compost and biochar. Bioresource Technology, 171, 274-284.

The opinions expressed in this chapter are those of the author(s) and do not necessarily reflect the views of the United Nations University Institute for Integrated Management of Material Fluxes and of Resources (UNU-FLORES), its Board of Directors, or the countries they represent.

Open Access This chapter is licensed under the terms of the Creative Commons Attribution 3.0 IGO license (https://creativecommons.org/licenses/by/3.0/igo/), which permits use, sharing, adaptation, distribution and reproduction in any medium or format, as long as you give appropriate credit to the United Nations University Institute for Integrated Management of Material Fluxes and of Resources (UNU-FLORES), provide a link to the Creative Commons license and indicate if changes were made.

Any dispute related to the use of the works of the United Nations University Institute for Integrated Management of Material Fluxes and of Resources (UNU-FLORES) that cannot be settled amicably shall be submitted to arbitration pursuant to the UNCITRAL rules. The use of the United Nations University Institute for Integrated Management of Material Fluxes and of Resources (UNU-FLORES)'s name for any purpose other than for attribution, and the use of the United Nations University Institute for Integrated Management of Material Fluxes and of Resources (UNU-FLORES)'s logo, shall be subject to a separate written license agreement between the United Nations University Institute for Integrated Management of Material Fluxes and of Resources (UNU-FLORES) and the user and is not authorized as part of this CC-IGO license. Note that the link provided above includes additional terms and conditions of the license.

The images or other third party material in this chapter are included in the chapter's Creative Commons license, unless indicated otherwise in a credit line to the material. If material is not included in the chapter's Creative Commons license and your intended use is not permitted by statutory regulation or exceeds the permitted use, you will need to obtain permission directly from the copyright holder.

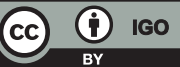

